\title{
Quick Incidental Learning of Words by Children with and without Specific Language Impairment: An Eye-tracking Study
}

\author{
Haeun Chung, Dongsun Yim \\ Department of Communication Disorders, Ewha Womans University, Seoul, Korea
}

Correspondence: Dongsun Yim, PhD Department of Communication Disorders, Ewha Womans University, 52 Ewhayeodae-gil, Seodamun-gu, Seoul 03760, Korea

Tel: $+82-2-3277-6720$

Fax: +82-2-3277-2122

E-mail: sunyim@ewha.ac.kr

Received: April 5, 2020

Revised: May 4, 2020

Accepted: May 7, 2020

This work was supported by the Ministry of Science and ICT of the Republic of Korea and the National Research Foundation of Korea (NRF2019R1A2C1007488).

\begin{abstract}
Objectives: This study's goal is to use eye-tracking technology to learn more about children's online novel word-learning processing abilities in a quick incidental learning (QUIL) task to examine how children with and without Specific Language Impairment (SLI) exhibit different patterns when learning new words and how these differences in looking behaviors lead to different learning results. Methods: Twenty typically developing (TD) children (age: $M=5.15$ years) and 10 children with $S L I$ (age: $M=5.11$ years) participated in the study. Children completed a QUIL task while their eye movements were recorded using an eyetracking device. The fixation count number and the average fixation time on target word AOls (Areas of Interest) were analyzed and heat map analysis was also conducted. Results: The analysis of eye-tracking measures revealed different patterns between groups. The TD group's fixation duration on AOls gradually increased from first to last exposure, whereas the SLI group showed decreased fixation duration over time. Heat map analysis showed that the SLI group fixated less on target AOls and their gazes were widely scattered compared to the gazes of the TD group. A positive correlation was observed between the fixation time and learning. Conclusion: For TD, words and their referents were correctly inferred and the association between words and referents was strengthened over time. Children with SLI had difficulty associating novel labels with novel objects, as indexed by less time spent looking at AOls. This study provides insights into the QUIL of words by children with and without SLI in a natural context.
\end{abstract}

Keywords: Quick incidental learning, Eye-tracking, Specific language impairment
Children with Specific Language Impairment (SLI) exhibit overall deficits in vocabulary development. A considerable body of evidence supports the view that children with SLI acquire words slower or less efficiently (Alt \& Plante, 2006; Akhtar, Jipson, \& Callanan, 2001; Dollaghan, 1987; Gray, 2004, 2005, 2006; McGregor, Friedman, Reilly, \& Newman, 2002). Children with word-learning difficulties would exhibit further deficits in other critical areas of development such as reading comprehension, morphological awareness, and grammar (Storch \& Whitehurst, 2002; Torppa, Lyytinen, Erskine, Eklund, \& Lyytinen, 2010), placing them at high risk for delayed academic achievement. Therefore, the word-learning process in SLI has been studied extensively by researchers and clinicians using several types of word-learning tasks such as fast mapping and the quick incidental learning (QUIL) paradigm.

\section{Quick Incidental Learning in SLI}

Fast mapping, an early stage of word learning in which children map a lexical label to a novel referent, is regarded as an essential skill for early vocabulary development. Researchers studying the word-learning processes have used the quick incidental learning (QUIL) paradigm to test the form-meaning mapping abilities (Rice, Buhr, \& Nemeth, 1990; Rice, Buhr, \& Oetting, 1992; Rice, Oetting, 
Marquis, Bode, \& Pae, 1994; Rice \& Woodsmall, 1988; Yim, Kim, \& Yang, 2015). Unlike fast mapping studies, QUIL minimized prompting from adults, and emphasized the incidental word learning in natural learning contexts. Unfamiliar words were introduced in the context of video clips. Researchers presented videos to children without mentioning that they had to learn the word. Then, researchers asked the children to choose the target word object from other pictures to assess their ability to pick up the meaning of the new words.

Studies showed that children with SLI demonstrated lesser word gain than typically developing (TD) peers in QUIL tasks (Horohov \& Oetiing, 2004; Oetting, Rice, \& Swank, 1995; Rice et al., 1990; Rice et al., 1992; Rice et al., 1994; Rice \& Bode, 1993; Rice \& Woodsamll, 1988; Yang \& Yim, 2018; Yang, Yim, \& Bae, 2015; Yang, Yim, Kim, \& Han, 2013; Yim et al., 2015). For instance, Yang and Yim (2018) presented a video that contained novel words throughout the story to 5-and 6-year-old children and conducted the picture comprehension task. Their results showed that children with vocabulary delay demonstrated less word gain than their TD peers. Some studies found a significant association between children's QUIL abilities and children's measured language abilities (Gordon, Schumm, Coffland, \& Doucette, 1992; Yang et al., 2013). For instance, QUIL ability has been shown to be an important factor that could predict the receptive vocabulary ability of TD children aged 2-6 (Yang et al., 2013). Studies that examine the incidental learning of words by children with SLI also suggested the effect of exposure to the word-learning process of children with SLI. Rice et al. (1994) reported that children with SLI were able pick up the meaning of the novel words in QUIL tasks, but they needed a greater input frequency than their TD peers to associate the meaning with the word (Rice et al., 1994). These studies showed that although children with SLI can infer word meaning without explicit assistance from adults, their performance is worse than that of their TD peers.

In summary, previous studies have revealed that children with SLI generally have poorer word-learning skills relative to children with typical development. Their performances on a QUIL comprehension tasks may reflect their impaired ability to acquire words' semantic representations. In addition, the fact that the SLI group performed worse on QUIL tasks than in comprehension tasks in fast-mapping settings suggests that the QUIL paradigm requires the ability to pick up the meaning of new words from their context. Furthermore, the meanings of the new words were only assessed in a comprehension task in which the children had to choose the appropriate picture that matched the target word. This makes it difficult to clearly identify the word-learning problems of children with SLI because this might reflect the partial semantic representations, rather than their complete knowledge of the word. Therefore, studies using fine-grain methodologies should be able to clarify the nature of the word-learning difficulties experienced by children with SLI.

\section{Eye-tracking studies of novel word learning in children} with and without SLI

In recent years, eye-tracking technology has shed light on the fundamentals of the language processing problems associated with SLI because the eye-tracking paradigm can provide a detailed examination of online language processing. The "visual world paradigm” (Cooper, 1974; McMurray, Munson, \& Tomblin, 2014; Tanenhaus, Spivey-Knowlton, Eberhard, \& Sedivy, 1995; Trueswell, 2008), involves recording the real-time eye movements while a story is presented simultaneously on a screen visually and audibly. The notion of the eye tracking is that what we look at closely corresponds to what we are thinking about (Henderson, 2003; Henderson \& Ferreira, 2004; Yarbus, 1967). This assumption is known as the “eye-mind assumption” (Just \& Carpenter; 1980), which means that looking behavior reflects attention. Studies that adopt this methodology demonstrated that fixation duration reflects processing demands and the amount of attention (Chambers, Tanenhaus, Eberhard, Filip, \& Carlson 2002; Hyönä, Lorch, \& Kaakinen, 2002; Trueswell \& Gleitman, 2007). Analyzing eye movements provides accurate and detailed information about which part of a task a child is having difficulty processing (Rayner, 1998, 2009) and can therefore both clarify our understanding of typical language development and provide a better understanding of the processing difficulties among clinical populations.

The eye-tracking paradigm has been intensively used by researchers to reveal the fundamental cognitive processes and mechanisms involved in novel word learning (Borovsky, Burns, Elman, \& Evans, 2013; Borovsky, Elman, Fernald, 2012; Ellis, Borovsky, 
Elman, \& Evans, 2015; Yu \& Smith, 2011), reading comprehension (Lum, Youssef, \& Clark, 2017; Rayner, Chace, Slattery, \& Ashby, 2006;), lexical processing (Borovsky et al., 2013; McMurray, Samelson, Lee, \& Tomblin, 2010), visual perception (Liversedge \& Findlay, 2000), autism (Brock, Norbury, Einav, \& Nation, 2008), dyslexia (Desroches, Joanisse, \& Robertson, 2006) and bilingualism (Bartolotti, Marian, Schroeder, \& Shook, 2011; Libben \& Titone, 2009; Pellicer-Sanchez, 2016; Pivneva, Mercier, \& Titone, 2014).

Recent studies using eye-tracking paradigms have provided useful insights that are helpful for examining the process of novel word learning. One study that examined college readers' eye movements demonstrated that college student readers were very sensitive to the presence of novel words (Wochna \& Juhasz, 2013). Novel words were more likely to be fixated upon and had longer reading times than words already in their vocabulary. Evans \& SaintAubin (2013) studied the four-year-old French-speaking children' $s$ vocabulary acquisition without adult explanations in repeated book reading. The results revealed that children made modest vocabulary gains on the words in the books, and these gains were related to their general receptive vocabulary. In particular, viewing time during their first reading on depictions of corresponding nouns in the story partially mediated the advantage of an overall receptive vocabulary held.

One study that examined the effects of different measures of word familiarity on eye-fixation times while reading showed the association between eye movement patterns during reading and post-test performance (Williams and Morris, 2004). There was a novel word condition that readers had no prior knowledge of the target word. After the reading session, participants had to select the correct meaning of the novel word from two possibilities in a vocabulary posttest. Thus, they established an association between online reading patterns and post-test performance. Readers (native English-speaking college students) tended to spend less initial processing time (i.e., shorter gaze duration) on the target words whose meaning they later identified correctly. Correctly defined words were associated with shorter gaze duration but longer second-pass times. However, Godfroid, Boers, and Housen (2013) examined the $\mathrm{L} 2$ reading of multisentential texts and showed that the longer participants looked at pseudo-words while reading, the more likely they were to recognize such words in the later vocabu- lary test. These two studies both indicated that eye movements are predictive of word-learning ability. Both studies showed that increases in later fixation time measures (second pass time and total time) facilitated word learning. In other words, paying focused attention to a novel word while reading has a beneficial effect on the encoding of that word in memory.

As mentioned above, several studies have applied the eye-tracking paradigm to learning; however, few have used eye-tracking technology to investigate the language difficulties of children with SLI. Studies on toddlers' cognitive processing have found that TD children were significantly faster and more accurate when looking at pictures of familiar words than children with SLI (Fernald \& Marchman, 2012; Mani \& Huetting, 2012). In addition, previous studies that employed eye-tracking techniques have found differences in eye-gaze patterns for children with SLI and their TD peers as they completed word-learning tasks (Borovsky et al., 2012; Borovsky et al., 2013; Ellis et al., 2015; Huettig \& Altmann, 2005; Yu \& Smith, 2011).

Studies that have examined the lexical and cognitive processing in infants and toddlers have found that late talkers are significantly slower and less accurate when looking at pictures of spoken familiar words in their vocabulary as compared to their normal language age-matched peers (Fernald \& Marchman, 2012; Mani \& Huetting, 2012). Furthermore, previous eye-tracking studies have found that both infants and children with SLI appear to have different gaze patterns during language processing and word-learning tasks as compared to normal language controls (Borovsky et al., 2012; Borovsky et al., 2013; Yu \& Smith, 2011). For example, Ellis et al. (2015) revealed differences in gaze fixation patterns in latetalker infants aged 18 months as they completed a test that asked the children to look at a novel target picture. The two groups in the study diverged between target and distractor pictures, although there was no difference in overall accuracy or reaction time to target. In addition, the results of real-time analysis of where children looked at the moment they heard the word that described their visual referent objects, the mean proportion of time spent looking at the target vocabulary was much larger. Another study by Yu and Smith (2011) of 14-16-months-old infants found that there were differences in eye gaze patterns between weak learners and strong learners, showing a close link between the gaze and learning. 
Other research suggested that children with diverse reading comprehension abilities had different numbers of fixations as they comprehended sentences (Nation, Marshall, \& Altmann, 2003; Rayner et al., 2006). Due to the processing and language difficulties among children with SLI, they show significantly longer average fixation time and total fixation time than TD children as they read and complete the reading comprehension tasks (Kang \& Yim, 2018). Kang and Yim (2018) examined the reading process and reading comprehension abilities of school-aged children using eye trackers, and their heat-map analysis revealed that children with SLI took longer to read the first part of a text and less time on the last part of the text, whereas children with typical development showed fixations throughout the entire text. The shorter average fixation time explains the lower amount of attention that children paid to the text and thus the poor reading comprehension performance of children with SLI. McMurray et al. (2010) also showed that adolescents with SLI fixated less on target pictures and fixated more on other pictures. Andreu, Sanz-Torrent, Guardia, and Macwhinney (2011) examined how preschool children with SLI processed narrative when they looked at the story presented on a screen while listening to the narration. The proportion of looks to the area that was the most semantically relevant to the story was greater for the TD group, as compared to children with SLI. Moreover, retelling was less accurate among children with SLI, including providing less information than children with typical development, and they showed a higher number of semantic and syntactic errors during the narrative retelling task.

Regarding the role of attention during learning, studies that used this paradigm have shown that the longer children fixated on novel words, the better they recognized those words in a post-test, indicating a positive correlation between attention and learning (Godfroid et al., 2013; Godfroid, Housen, \& Boers, 2010, MacRoyHiggins \& Montemarano, 2016; Montero Perez, Peters, \& Desmet, 2015). In addition, studies demonstrated differences in attention between TD children and children with SLI in situations with cognitive processing demands (Lum, Youssef, \& Clark, 2017). They investigated the attention allocations associated with sentence comprehension by examining the pupil size of children with and without SLI. Comparisons of the pupil size between groups revealed that the SLI group had larger pupil sizes than the TD group when comprehending easy sentences. These findings provide evidence that learning depends on the looking behaviors, which reflect the distribution of attention.

In summary, findings using various experimental methods suggest that the word-learning skill evolves into childhood and that children with and without SLI exhibit different patterns when learning words. However, it is unclear what factors affect the learning performance and what kind of online processing difficulties children with SLI experience when learning new words. Moreover, although several eye-tracking studies have revealed the time course of novel word learning, preschool children's online language processing abilities in naturalistic, oral contexts have not been studied. Thus, through using an eye-tracking technology in a QUIL task, this study's goal is to examine how children with and without SLI exhibit different patterns when learning new words and how these differences in looking behaviors can lead to different learning results.

\section{The Current Study}

This study's goal is to investigate the eye-gaze patterns of children with and without SLI as they complete a QUIL task to gain further insights into their online novel word-learning processing abilities in a QUIL task. The following research questions were addressed:

1. Are there significant group differences in QUIL performance?

2. Are there group differences in eye movement patterns when learning novel words? How does this pattern change across three encounters?

3. Is there a significant correlation between eye movement measures and word recognition in the posttest?

\section{METHODS}

\section{Participants}

Thirty children participated, 20 with typical speech and language development (TD group) and 10 with SLI (SLI group). All were recruited from Seoul and Chungnam areas. The TD group were in the age range 4;5 (years; months) to 6;2 (Mean age $=5.15$ ) and the SLI group ranged from 4;0 to 5;11 (Mean age=5.11). All children were reported to have normal hearing and had no history 
Table 1. Participant description information: Means (SDs in Parentheses)

\begin{tabular}{lccc}
\hline Measure & $\mathrm{SLI}(\mathrm{N}=10)$ & $\mathrm{TD}(\mathrm{N}=20)$ & $p$ \\
\hline Age in months & $61.4(7.79)$ & $61.9(9.1)$ & $\mathrm{ns}$ \\
Non-verbal IO $^{\mathrm{a}}$ & $106.35(8.88)$ & $110.35(9.74)$ & $\mathrm{ns}$ \\
Language age $^{\mathrm{b}}$ & & & \\
Receptive & $49.3(10.75)$ & $68.3(10.54)$ & $* * *$ \\
Expressive & $43.1(11.0)$ & $65.5(7.79)$ & $* * *$ \\
\hline
\end{tabular}

$\mathrm{TD}$ = typically developing children; $\mathrm{SLI}=$ children with specific language impairment. aKorean Kaufman Assessment Battery for Children (K-ABC; Moon \& Byun, 2003), ${ }^{b}$ Preschool Receptive-Expressive Language Scale (Kim, Sung, \& Lee, 2003).

${ }^{* * *} p<.001$.

of cognitive, emotional, or social disorders or delays. There were no significant differences between the average chronological ages of the two groups $(p>.05)$. Table 1 presents participant description information.

All participants completed standardized language and cognitive tests to determine their eligibility for participation and they all achieved a standard score $>85$ on the Korean Kaufman Assessment Battery for Children (K-ABC; Moon \& Byun, 2003). The children's language abilities were assessed using the Preschool Receptive-Expressive Language Scale (PRES; Kim, Sung, \& Lee, 2003). PRES is a standardized test that assesses both the expressive and receptive language abilities of children aged 2-6 years using various objects that are familiar to the children such as picture books and toys. Children were asked to follow the examiner's instructions and answer the questions. The SLI group exhibited a significantly lower receptive and expressive language age than the TD groups in the PRES at the $p<.001$ level (receptive language delayed for six months; expressive language delayed for a year or more).

\section{Materials and Procedures}

\section{Quick Incidental Learning}

This study used Yang et al. (2013)'s QUIL task. Each set consisted of five novel words and two sets of novel words were embedded in separate stories. Appendix 1 shows the novel words used in the study. 10 novel words (non-words) were used as labels of the referents throughout the experiment. An object and action were selected to correspond to the referent for each novel word. The target words were seven nouns and three verbs. Nouns all have a CVCV structure and verbs have CVCVCV structure, with the same word form used in Korean language.
Two animations used in the task were "Der Maulwurf und der Fernseher" and "Der Maulwurf und Ei" selected from the German animation website. Stories were modified into Korean and was recorded by a female Korean speaker; they were presented as video files with simple animations and each was approximately five minutes long. The stimuli, syntax structures, and story structure used in the QUIL task were verified by 2 speech-language pathologists who have trained more than 10 years in the field and five doctoral students in the Department of communication disorders. The validity of the task came out $98 \%$.

Each novel word was embedded in a sentence and appeared three times in the story (e.g., 'He dropped meku', 'He picked up meku', 'He puts meku on the house') to find out the effect of exposures to the word-learning process of children. The story used in this study is presented in the Appendix 2. The average times that the target words appeared in the story were 146.7 seconds for the 1st exposure, 154.55 seconds for the 2nd exposure, and $168.88 \mathrm{sec}$ onds for the 3 rd exposure. Thus, the time interval between the 1st and 2nd exposures was 7.77 seconds on average, and the time interval between the 2 nd and 3rd exposures was 14.33 seconds on average.

The researchers instructed the children to watch and listen to the story with no explicit instruction to pay attention to the novel words in the video. After watching the animation, participants completed a receptive vocabulary test that asked them about the novel words in the video. For the receptive test, children were requested to choose the target word picture from the other pictures presented on the screen. For example, when a tester asks, "Where is the 'puki' you saw in the video among these four pictures?", a child points to a painting that he thinks is 'puki'.

\section{Eye tracking}

During the QUIL task, children's eye movements were recorded with an infrared remote eye-tracking system (RED) from SensoMotoric Instruments (SMI) with a $60 \mathrm{~Hz}$ sampling rate. Its software provided several visualizations and analyses that allowed for a research setting that combines qualitative and quantitative evaluations (Cheng, 2011). This device is designed to detect faces, eyes, pupils, and the corneal reflections from the infrared light sources and provide data about the pupil position, eye movement, and gaze 
directions. This equipment is very precise in that it can measure up to 250 pupil movements per second, which is suitable for language experiments. Furthermore, it has the advantage that it permits free head movement. The subject could use it without making physical contact.

Participants were seated approximately $60-70 \mathrm{~cm}$ from the screen that was set up with an eye tracker. The session started with calibrating the eye tracker to ensure the eye-tracking data's validity. The calibration procedure used a five-point calibration method in which the position of the eye was traced by the equipment and the stimuli on the monitor had to correspond with the eye position. The children had to fixate on five faces of a famous cartoon character that appeared at the center of the screen, then the bottom left, bottom right, top left, and finally the top right. The difference between both measurements (points on the screen and the child's fixation point) had to be within $0.5^{\circ}$ to be considered successful. If the calibration data was poor or missing, recalibration was required. The initial five-point calibration procedure took less than five minutes and was completed before each video started.

After calibration, the experimenter explained that the participants were going to watch a five-minute animation and that they could look anywhere on the screen while listening to the story. The entire session lasted approximately $15 \mathrm{~min}$.

The visual display was designed for a 24 -inch monitor with a $1,920 \times 1,080$ px resolution. An area of interest (AOI) that matched the novel word was defined for each target picture. The size of the area of interest (AOI) for each target was defined 10,000-30,000 px that was occupied by the drawing of the target words. The average size of the 30 AOIs in total was 109,610 px. The AOI coverage (\%) of the screen was in the range $10-30 \%$ for all words. AOIs were used to calculate typical statistical indicators such as sequence, entry time, dwell time, hit ratio, average fixation, and fixation count. In this study, among those measures, the fixation count number and the average fixation time per AOI were calculated and analyzed across three encounters. Furthermore, the looking distribution over the stimulus was presented using heat maps.

\section{Analysis}

In the QUIL task, the number of correct responses was calculated in the receptive vocabulary test. The task was one point per word, and the total score was 10 . The scores were converted to percentiles (\%) in the analysis.

The eye-tracking measures that were analyzed in this study were the fixation count number and the average fixation time on AOI and heat map. The fixation count for every target word AOI was analyzed. The mean and standard deviation of the fixation time spent on AOIs for each child for each target word AOI was calculated for each child. As in Bergstrom and Schall (2014), data with $<75 \%$ of eye-tracking ratio were excluded from the analysis. All 30 participants' data were used for data analysis because the tracking ratio was $>75 \%$. Experiments were designed using the "Experiment center 3.1" program from SMI and the children's learning processes were measured using iView XTM RED equipment. Then, the eye movement data were analyzed using the "Be Gaze 3.5 " software.

In this study, the eye movement measures of interest were the number of fixation count and the proportion of time spent in the target word AOI. To see how the two groups continued to pay attention to each target word AOI, the number of fixation count and average gaze duration were analyzed for all 10 AOIs.

The number of gaze fixations for that area can be interpreted as the subject's perception of the information in that area as important, or that it attracted the subject's attention (Holmqvist et al., 2011). In addition, the average fixation duration (ms), refers to the time that the gaze remained on average in one gaze count. A longer average fixation time can be interpreted as more cognitive processing occurring in the area or that the area attracted more attention from the viewer (Holmqvist et al., 2011; Poole \& Ball, 2006). Thus, analyzing the fixation count and average fixation time will provide information about whether children pay attention to the AOIs of novel words presented in the animation.

Gaze fixation is mainly defined based on the degree of distribution and duration of the eye focus (Holmqvist et al., 2011). The degree of distribution can be expressed as the angle formed between the eye coordinates based on the pixel or the eyeball, and the duration can be expressed in units of milliseconds (ms). In general, gaze fixation is defined as a fixation that is located within $0.5-2.0^{\circ}$ and that stays for more than 40-200 milliseconds (Engelmann, Damaraju, Padmala, \& Pessoa, 2009). However, the definition of a fixation depends on the task type: $>40 \mathrm{~ms}$ for the reading task, and 
$>200 \mathrm{~ms}$ for the picture task (Holmqvist et al., 2011). Therefore, gaze fixation was set at $2.0^{\circ}$ and $150 \mathrm{~ms}$ in this study to reflect the figure and the image. Gaze patterns were visualized using heat maps in which colors are used to represent the overall amount of attention, ranging from red (most) to blue (least). Hit Ratio (\%) indicates how many subjects out of those selected subjects looked at least once time into the AOI and is calculated as the "total hit count"/ "number of selected subjects."

The statistical analyses were conducted using SPSS ver. 22.0 (IBM, Armonk, NY, USA). A one-way Analysis of Variance (ANOVA) was used to compare the group performances on the QUIL task (number of words learned). The Shapiro-Wilk test was used to examine the within-group score distributions. Eye movement pattern differences were examined between the groups for the task using a two-way ANOVA with the group (SLI or TD) as the between-group variable and exposure $(1,2$, or 3$)$ as the within-group variable. Correlation analysis was conducted between eye movement measures and the word recognition on the task to examine the association between eye movement measures and the number of words learned.

\section{RESULTS}

\section{QUIL performance}

The QUIL performance scores for children with and without SLI are presented in Table 2. The QUIL scores were converted into

Table 2. Means and standard deviations for percentage or correct responses in QUIL receptive vocabulary test

\begin{tabular}{lccc}
\hline & SLI $(\mathrm{N}=10)$ & $\mathrm{TD}(\mathrm{N}=20)$ & $p$ \\
\hline QUIL score & $40.09(5.78)$ & $57.27(17.96)$ & $.027^{*}$ \\
\hline
\end{tabular}

Values are presented as mean (SD).

QUIL=quick incidental learning; $S L I=$ specific language impairment; $T D=$ typically developing.

${ }^{*} p<.05$. percentiles for the analysis. To determine whether the QUIL performance varied between groups, this study analyzed the QUIL score with a one-way analysis of variance (ANOVA) with the group (SLI, TD) as the between-participants factor. The one-way ANOVA results showed that there was an overall significant group difference in the QUIL task scores $\left(F_{(1,28)}=5.463, p<.05\right)$.

\section{Eye movement measures}

Among eye-tracking measures, this study analyzed fixation count and average fixation time.

The differences in the fixation count number across three encounters were compared by conducting a two-way repeated ANOVA was conducted with "exposure" $(1,2$, or 3$)$ as a within-participants factor and "group" (SLI or TD) as a between-participants factor. In terms of interactions between group and exposure, the groups did not differ in the fixation count number on the target word AOIs $\left(F_{(1,28)}=1.8648, p>.05\right)$.

The two-way ANOVA's results yielded a significant main effect for group $\left(F_{(1,28)}=10.274, p<.05\right)$, indicating that there was a longer average fixation time for the TD group compared to the SLI group; these results are illustrated in Table 3. In addition, a significant Group $\times$ Exposure interaction was found $\left(F_{(1,28)}=10.418, p=\right.$ .003). The interaction contrast was performed using LMATRIX and MMTRIX. The test of the interaction showed that the there was no significant group difference for the average fixation time between the 1st and 2nd exposures $\left(F_{(1,28)}=.272, p=.060\right)$, but there was a significant group difference at the 1 st and $3 \mathrm{rd}\left(F_{(1,28)}=10.418\right.$, $p=.003)$, and at 2 nd and 3rd exposures $\left(F_{(1,28)}=12.131, p=.002\right)$. Figure 1 shows a graph of the average time spent across the three encounters by children with and without SLI. The time interval between the 1st and 2nd exposure was 7.77 seconds on average, and the time interval between the 2 nd and 3 rd was 14.33 seconds on average.

Table 3. Average number of fixation count and fixation time (ms) for each group

\begin{tabular}{|c|c|c|c|c|c|c|}
\hline \multirow{2}{*}{ Group } & \multicolumn{3}{|c|}{ Average number of fixation count } & \multicolumn{3}{|c|}{ Average fixation time (ms) } \\
\hline & 1st exposure & 2nd exposure & 3rd exposure & 1st exposure & 2nd exposure & 3rd exposure \\
\hline $\mathrm{TD}(\mathrm{N}=20)$ & $2.0(0.64)$ & $1.80(0.50)$ & $2.41(0.60)$ & $363.990(96.37)$ & 435.909 (99.43) & $548.581(150.50)$ \\
\hline SLI (N=10) & $1.89(0.67)$ & $1.81(0.71)$ & $2.60(0.72)$ & $332.975(113.93)$ & $375.326(148.89)$ & 315.332 (85.79) \\
\hline
\end{tabular}

Values are presented as mean (SD).

$\mathrm{SLI}=$ specific language impairment; TD=typically developing. 


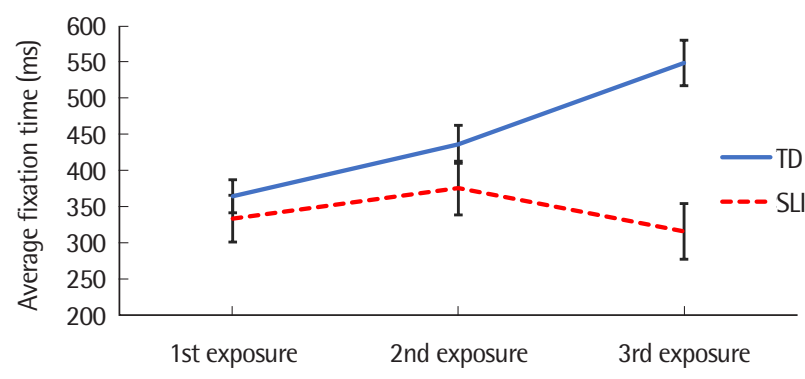

Figure 1. Average fixation time by Exposures in children with and without SLI. $S L I=$ specific language impairment; $T D=$ typically developing.

Table 4. Hit ratio (\%) of AOls by Group

\begin{tabular}{lll}
\hline & TD $(\mathrm{N}=20)$ & SLI $(\mathrm{N}=10)$ \\
\hline AOI1 & $73.6(21.4)$ & $73.3(11.5)$ \\
AOI2 & $79.1(18.1)$ & $70.0(10.0)$ \\
AOI3 & $76.6(20.8)$ & $61.1(22.9)$ \\
AOI4 & $84.7(6.3)$ & $70.0(11.5)$ \\
AOI5 & $88.9(8.6)$ & $80.0(20.0)$ \\
AOI6 & $75.0(9.0)$ & $54.5(24.0)$ \\
AOI7 & $84.0(5.0)$ & $90.9(9.1)$ \\
A018 & $93.9(2.4)$ & $88.0(5.2)$ \\
AOI9 & $85.5(17.6)$ & $69.7(20.9)$ \\
AOI10 & $81.0(13.9)$ & $66.6(31.9)$ \\
\hline
\end{tabular}

Values are presented as mean (SD).

$\mathrm{AOI}=$ Area of Interest; $\mathrm{SLI}=$ specific language impairment; $\mathrm{TD}=$ typically developing .

\section{Heat map analysis}

The heat map is a visualization of where the two groups stared during the QUIL task. The areas indicated by "hotter" colors indicate where the eye was fixated. The heat map shows fixation hits associated with a range of colors from blue (fewer hits) to red (most hits). Green indicates areas where gaze fixation occurred for $>100$ $\mathrm{ms}$, yellow for $>200 \mathrm{~ms}$, and red for $>300 \mathrm{~ms}$. Figure 2 below shows how children with and without SLI looked at a total of 10 target word AOIs.

Heat-map analysis revealed that TD children fixated more on the target vocabulary AOIs and that their gazes were clustered on target AOIs. Meanwhile, the SLI group fixated less on the target $\mathrm{AOI}$ and their gazes were widely scattered compared to the gazes of the TD group.

Since heat maps provide a general aggregation of fixations, the hit ratio (\%) for each AOI were used to examine the distribution of children's' attention in greater detail. The hit ratio (\%) revealed that the TD group showed a higher hit ratio (\%) than the SLI group
Table 5. Correlations between eye tracking measures and QUIL

\begin{tabular}{lc}
\hline & QUIL score \\
\hline Fixation count & .076 \\
Average fixation time & $.429^{*}$ \\
\hline
\end{tabular}

QUIL= quick incidental learning.

${ }^{*} p<.05$.

in general, which indicates that typically developing children paid more attention to the novel word referents compared to their peers with SLI. Table 4 lists the hit ratios (\%) of all AOIs.

\section{Correlation analysis}

Correlational analyses (Table 5) revealed that there was a positive relationship between total average fixation time and word recognition $(\mathrm{r}=.429, p<.05)$. However, there was no relationship between fixation count and word recognition of the word on the posttest.

\section{DISCUSSION}

\section{Quick incidental learning of words by children with SLI}

Children with SLI aged 4 to 6 who participated in this study performed poorer on the QUIL task than their typically developing peers. The QUIL task was designed to assess the children's ability to learn new words inserted in a five-minute long animation, which is a relatively natural context; that is, the participants were not explicitly asked to learn in this situation. Associating words and objects in a naturalistic environment is difficult as many possible referents and many possible words are simultaneously present at the learning moment. The results demonstrated that children with SLI have deficits in quick incidental learning, which is consistent with previous findings that reported a lack of fast mapping ability in SLI (Alt, 2013; Jackson, Leitao, \& Clasessen, 2016; Yang et al., 2013).

\section{Eye movements by group across the three encounters}

Using the eye tracker, the number of fixation count and average fixation time for each target word AOI across the three encounters were compared between the SLI and TD groups. The two groups did not differ significantly in the number of fixation counts for AOI, but there was a significant difference between the 1st and 3rd 


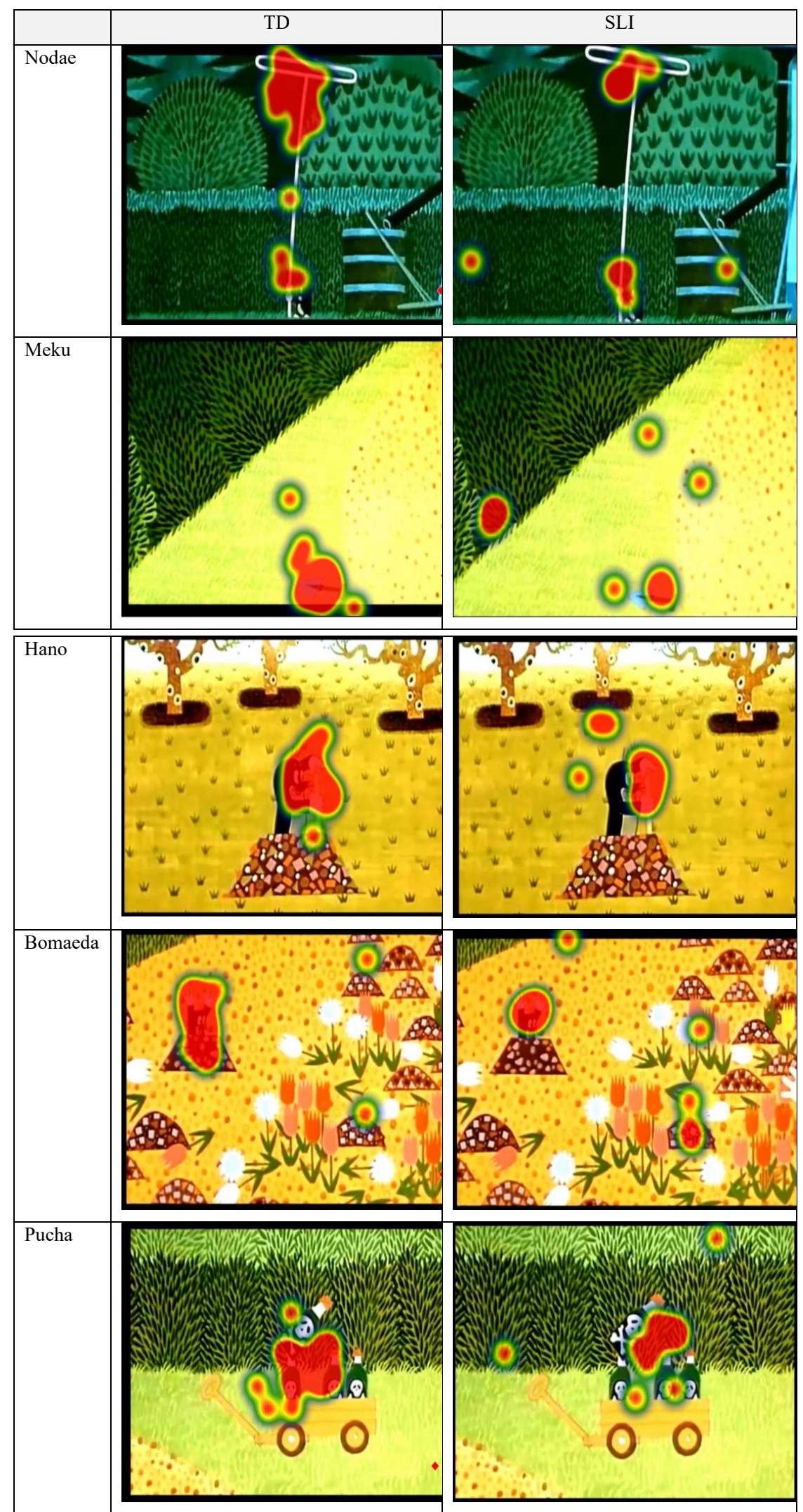

Figure 2. Heat map analysis.

SLI = specific language impairment; TD= typically developing. (Continued to the next page) 


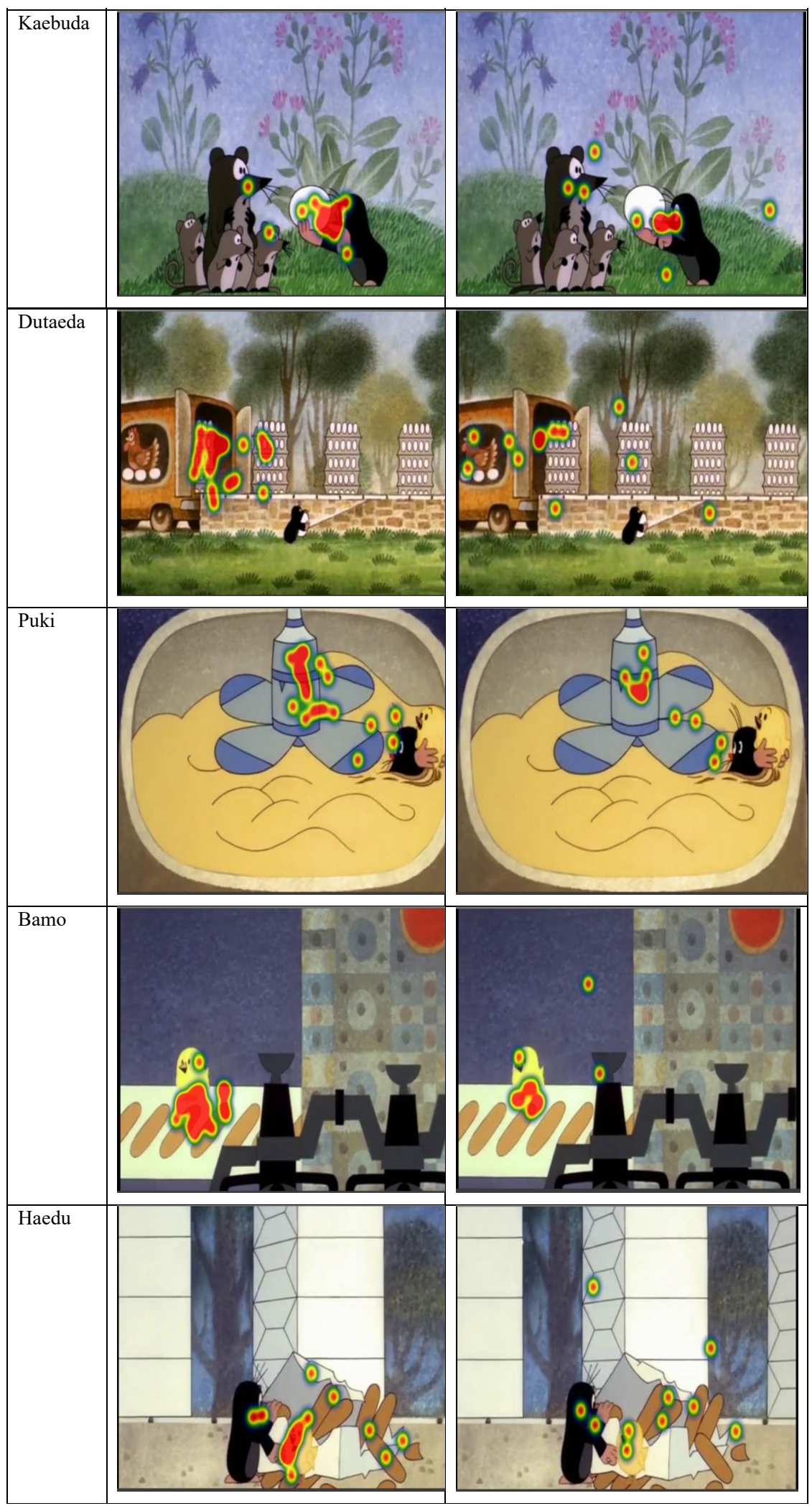

Figure 2. Continued. 
encounters, showing the main effect of exposures. This indicates that the number of fixation count increased over time.

Further analysis of the average fixation time difference between the TD and SLI groups across the three encounters was conducted. Overall, children with SLI showed lower average fixation times on AOIs compared to the age-matched normal group. In addition, there was a significant difference in the average fixation time between the groups across three encounters. For children with typical development, the average fixation time gradually increased from the first to the last exposure, whereas the average fixation time decreased among the children with SLI, showing a significant difference in their eye gaze patterns while learning new words. Thus, the greatest difference in the viewing proportion occurred at the last exposure.

Heat-map analysis revealed that the gaze of typically developing children was mainly on the target vocabulary AOIs. Meanwhile, the SLI group fixated less on the target AOIs and their gazes were widely scattered (compared with the gazes of the TD group). Along with heat-map visualization, the hit ratio (\%) revealed that the TD children generally showed a higher hit ratio (\%) than the SLI group, which indicates that the TD children paid more attention to the novel word referents than their peers with SLI as they heard novel words.'

In addition, different gaze patterns were found between the groups across the three exposures. TD children showed increased fixation time from the first to last exposure, whereas children with SLI showed decreased fixation time over time. The results suggest that children with SLI have difficulty associating novel referents with a label. The assumption that drives the eye-tracking research is that what we look at closely corresponds to what we are thinking about (Cooper, 1974; Henderson \& Ferreira, 2004; Just, Carpenter; 1980; Yarbus, 1967). Looking for longer creates learning, and longer fixation time on a particular area indicates that cognitive processing has occurred for that area (Henderson \& Hollingsworth, 1998; Holmqvist et al., 2011; Yu \& Smith, 2011). In addition, studies on word-referent mapping have demonstrated that individuals tend to look toward objects that are referred to by speech (Griffin, 2001; Johnson, Amso, \& Slemmer, 2003; McMurray \& Aslin, 2004; Trueswell, \& Gleitman, 2007; Yu \& Smith, 2011). This study found that typically developing children fixated more on novel object AOIs than children with SLI. Thus, typically developing children spent more time processing novel labels and novel referents and they successfully associated the two. For TD children, words and their referents were correctly inferred and the association between words and referents was strengthened over time. Meanwhile, children with SLI had difficulty associating novel labels with novel objects, as indexed by the less time they spent looking at AOIs in general.

There was no significant group difference in average fixation time between the 1st and 2nd exposures, but there was a significant group difference between 1st and 3rd and between 2nd and 3rd exposures. The greatest group difference in the viewing proportion occurred at the last exposure. Each target word appeared three times in the task, and the average times the words were presented in the 1st, 2nd, and 3rd exposures were 146.7s, 154.5s, and $168.8 \mathrm{~s}$, respectively. The time interval between the 1 st and $2 \mathrm{rd}$ exposure and the 2 nd and 3 rdexposurews were $7.7 \mathrm{~s}$ and $14.3 \mathrm{~s}$, respectively.

One possible reason for the observed group time difference is that the children with SLI may have failed to consistently stabilize their attention. These findings are consistent with previous studies that reported a close link between eye movements and attention direction (Altmann \& Kamide, 2007; Colombo, 2001; Hanley et al., 2014; Holmqvist et al., 2011; Huettig, Rommers, \& Meyer, 2011; Mishra \& Hillyard, 2009; Rayner, 1998; Yu, Smith, 2011). In addition, studies have reported the attentional differences between children with SLI and TD children in sentence comprehension (Lum et al., 2017), novel word recognition (Ellis et al., 2015; Yu \& Smith, 2011), and narrative comprehension (Andreu et al., 2011). For example, in Yu and Smith (2011)'s word-learning study, infants with strong statistical learning ability had more stable eye-movement patterns for sustained attention characterized by longer fixation, indicating that infants required more sustained attention to cognitively register word-object associations. The results suggest that a longer fixation indicates more stable attention, and thus better learning. Furthermore, there are numerous studies that have reported the attentional control problems among children with SLI (Montgomery, Evans, \& Gillam, 2009; Noterdaeme, Amorosa, Mildenberger, Sitter, \& Minow, 2001; Pons, Andreu, Sanz-Torrent, Buil-Legaz, \& Lewkowicz, 2013; Stevens, Sanders, \& Neville, 2006). In line with the body of literature, it can be concluded that children 
with SLI do not organize attention well and thus fail to strengthen their association between the novel labels and objects. Children with SLI's shorter fixation time, particularly at the 3rd exposure, indicate less stabilized attention and that they learned word-object associations less frequently than the TD group. Thus, attentional difficulties make it difficult for children with SLI to both keep track of and successfully associate novel words and their referents.

The correlation analysis indicates that correctly identified words were more likely to be fixated for longer. The amount of time children spent looking at the corresponding object when they heard the word mediated their overall recognition of that word in the receptive test administered after watching the video. This finding generally agrees with previous studies that reported a correlation between fixation time and learning, i.e. the longer they looked at novel words, the greater learning gains they reported, particularly in meaning recognition and recall of these words. (Bisson, Heuven, Conklin, \& Tunney, 2014; Bisson, Van Heuven, Conklin, \& Tunney, 2015; Godfroid et al., 2013; Pellicer-Sanchez, 2016; Williams \& Morris, 2004). Thus, it can be concluded that increased fixation time facilitates word learning. In other words, paying attention to a novel word while looking and listening to the narrative affects the learning of that word.

\section{CONCLUSION}

This eye-tracking study revealed different gaze patterns between children with and without SLI as they learn new words in a natural context. For TD children, words and their referents were correctly inferred and the association between words and referents was strengthened over time. Children with SLI had difficulty associating novel labels with novel objects, as indexed by the less time they spent looking at AOIs. There have only been a handful of studies that used an eye-tracking technology to analyze the learning process of children with SLI in a natural context. While previous studies findings have suggested that children with SLI have difficulty in quick incidental learning tasks, traditional quick incidental learning paradigms could not examine the real-time learning process in detail that may have been helpful for characterizing the word-learning deficits children with SLI have. This eye-tracking study provides insights into the quick incidental learning tasks for children with and without SLI in a natural context.

\section{REFERENCES}

Akhtar, N., Jipson, J., \& Callanan, M. A. (2001). Learning words through overhearing. Child Development, 72(2), 416-430.

Alt, M. (2013). Visual fast mapping in school-aged children with specific language impairment. Topics in Language Disorders, 33(4), 328-346.

Alt, M., \& Plante, E. (2006). Factors that influence lexical and semantic fast mapping of young children with specific language impairment. Journal of Speech, Language, and Hearing Research, 49(5), 941-954.

Altmann, G. T., \& Kamide, Y. (2007). The real-time mediation of visual attention by language and world knowledge: linking anticipatory (and other) eye movements to linguistic processing. Journal of Memory and Language, 57(4), 502-518.

Andreu, L., Sanz-Torrent, M., Guàrdia Olmos, J., \& Macwhinney, B. (2011). Narrative comprehension and production in children with SLI: an eye movement study. Clinical Linguistics \& Phonetics, 25(9), 767-783.

Bartolotti, J., Marian, V., Schroeder, S. R., \& Shook, A. (2011). Bilingualism and inhibitory control influence statistical learning of novel word forms. Frontiers in Psychology, 2(324), 1-10.

Bergstrom, J. R., \& Schall, A. (2014). Eye tracking in user experience design. Amsterdam Boston: Elsevier.

Bisson, M. J., Heuven, W. J., Conklin, K., \& Tunney, R. J. (2014). The role of repeated exposure to multimodal input in incidental acquisition of foreign language vocabulary. Language Learning, 64(4), 855-877.

Bisson, M. J., Van Heuven, W. J., Conklin, K., \& Tunney, R. J. (2015). The role of verbal and pictorial information in multimodal incidental acquisition of foreign language vocabulary. The Quarterly Journal of Experimental Psychology, 68(7), 1306-1326.

Borovsky, A., Burns, E., Elman, J. L., \& Evans, J. L. (2013). Lexical activation during sentence comprehension in adolescents with history of specific language impairment. Journal of Communication Disorders, 46(5), 413-427.

Borovsky, A., Elman, J. L., \& Fernald, A. (2012). Knowing a lot for one’s age: vocabulary skill and not age is associated with anticipatory incremental sentence interpretation in children and adults. Journal of Experimental Child Psychology, 112(4), 417-436.

Brock, J., Norbury, C., Einav, S., \& Nation, K. (2008). Do individuals with autism process words in context? Evidence from language-mediated eyemovements. Cognition, 108(3), 896-904. 
Chambers, C. G., Tanenhaus, M. K., Eberhard, K. M., Filip, H., \& Carlson, G. N. (2002). Circumscribing referential domains during real-time language comprehension. Journal of Memory and Language, 47(1), 30-49.

Cheng, S. (2011). The research framework of eye-tracking based mobile device usability evaluation. Proceedings of the 1st international workshop on pervasive eye tracking \& mobile eye-based interaction, 21-26.

Colombo, J. (2001). The development of visual attention in infancy. Annual Review of Psychology, 52(1), 337-367.

Cooper, R. M. (1974). The control of eye fixation by the meaning of spoken language: a new methodology for the real-time investigation of speech perception, memory, and language processing. Cognitive Psychology, 6(1), 84-107.

Desroches, A. S., Joanisse, M. F., \& Robertson, E. K. (2006). Specific phonological impairments in dyslexia revealed by eyetracking. Cognition, 100(3), B32-B42.

Dollaghan, C. A. (1987). Fast mapping in normal and language-impaired children. Journal of Speech and Hearing Disorders, 52(3), 218-222.

Ellis, E. M., Borovsky, A., Elman, J. L., \& Evans, J. L. (2015). Novel word learning: an eye-tracking study. Are 18-month-old late talkers really different from their typical peers? Journal of Communication Disorders, 58, 143-157.

Engelmann, J. B., Damaraju, E., Padmala, S., \& Pessoa, L. (2009). Combined effects of attention and motivation on visual task performance: transient and sustained motivational effects. Frontiers in Human Neuroscience, 3, 4.

Evans, M. A., \& Saint-Aubin, J. (2013). Vocabulary acquisition without adult explanations in repeated shared book reading: an eye movement study. Journal of Educational Psychology, 105(3), 596-608.

Fernald, A., \& Marchman, V. A. (2012). Individual differences in lexical processing at 18 months predict vocabulary growth in typically developing and late-talking toddlers. Child Development, 83(1), 203-222.

Godfroid, A., Boers, F., \& Housen, A. (2013). An eye for words: gauging the role of attention in incidental L2 vocabulary acquisition by means of eyetracking. Studies in Second Language Acquisition, 35(3), 483-517.

Godfroid, A., Housen, A., \& Boers, F. (2010). A procedure for testing the Noticing Hypothesis in the context of vocabulary acquisition. In M. Putz \& L. Sicola (Eds.), Cognitive processing in second language acquisition: inside the learner's mind (pp. 169-197). Amsterdam: John Benjamins.

Gordon, J., Schumm, J. S., Coffland, C., \& Doucette, M. (1992). Effects of inconsiderate versus considerate text on elementary students'vocabulary learning. Reading Psychology: An International Quarterly, 13(2), 157-169.

Gray, S. (2004). Word learning by preschoolers with specific language im- pairment: predictors and poor learners. Journal of Speech, Language, and Hearing Research, 47(5), 1117-1132.

Gray, S. (2005). Word learning by preschoolers with specific language impairment: effect of phonological or semantic cues. Journal of Speech, Language, and Hearing Research, 48(6), 1452-1467.

Gray, S. (2006). The relationship between phonological memory, receptive vocabulary, and fast mapping in young children with specific language impairment. Journal of Speech, Language, and Hearing Research, 49(5), 955-969.

Griffin, Z. M. (2001). Gaze durations during speech reflect word selection and phonological encoding. Cognition, 82(1), B1-B14.

Hanley, M., Riby, D. M., McCormack, T., Carty, C., Coyle, L., Crozier, N., ... \& McPhillips, M. (2014). Attention during social interaction in children with autism: comparison to specific language impairment, typical development, and links to social cognition. Research in Autism Spectrum Disorders, 8(7), 908-924.

Henderson, J. M. (2003). Human gaze control during real-world scene perception. Trends in Cognitive Sciences, 7(11), 498-504.

Henderson J. Hollingworth A. (1998). Eye guidance while reading and while watching dynamic scenes. In Underwood G (Ed.), Eye movements during scene viewing: An overview (pp. 269-293). Oxford, UK: Elsevier.

Henderson, J. M., \& Ferreira, F. (2004). Scene perception for psycholinguists. In J. M. Henderson \& F. Ferreira (Eds.), The interface of language, vision and action (pp. 1-58). Hove: Psychology Press.

Holmqvist, K., Nyström, M., Andersson, R., Dewhurst, R., Jarodzka, H., \& Van de Weijer, J. (2011). Eye tracking: A comprehensive guide to methods and measures. New York: Oxford University Press.

Horohov, J. E., \& Oetting, J. B. (2004). Effects of input manipulations on the word learning abilities of children with and without specific language impairment. Applied Psycholinguistics, 25(1), 43-65.

Huettig, F., \& Altmann, G. T. (2005). Word meaning and the control of eye fixation: semantic competitor effects and the visual world paradigm. Cognition, 96(1), B23-B32.

Huettig, F., Rommers, J., \& Meyer, A. S. (2011). Using the visual world paradigm to study language processing: A review and critical evaluation. Acta Psychologica, 137(2), 151-171.

Hyönä, J., Lorch Jr, R. F., \& Kaakinen, J. K. (2002). Individual differences in reading to summarize expository text: evidence from eye fixation patterns. Journal of Educational Psychology, 94(1), 44.

Jackson, E., Leitao, S., \& Claessen, M. (2016). The relationship between pho- 
nological short-term memory, receptive vocabulary, and fast mapping in children with specific language impairment. International Journal of Language \& Communication Disorders, 51(1), 61-73.

Johnson, S. P., Amso, D., \& Slemmer, J. A. (2003). Development of object concepts in infancy: evidence for early learning in an eye-tracking paradigm. Proceedings of the National Academy of Sciences, 100(18), 10568-10573.

Just, M. A., \& Carpenter, P. A. (1980). A theory of reading: from eye fixations to comprehension. Psychological Review, 87(4), 329.

Kang, S., \& Yim, D. (2018). Reading comprehension and reading processing of school-aged children with specific language impairment. Communication Sciences and Disorders, 23(4), 914-928.

Kim, Y. T., Sung, T. J., \& Lee, Y. (2003). Preschool receptive \& expressive scale (PRES). Seoul: Seoul Community Rehabilitation Center.

Libben, M. R., \& Titone, D. A. (2009). Bilingual lexical access in context: evidence from eye movements during reading. Journal of Experimental Psychology: Learning, Memory, and Cognition, 35(2), 381.

Liversedge, S. P., \& Findlay, J. M. (2000). Saccadic eye movements and cognition. Trends in Cognitive Sciences, 4(1), 6-14.

Lum, J. A., Youssef, G. J., \& Clark, G. M. (2017). Using pupillometry to investigate sentence comprehension in children with and without specific language impairment. Journal of Speech, Language, and Hearing Research, 60(6), 1648-1660.

MacRoy-Higgins, M., \& Montemarano, E. A. (2016). Attention and word learning in toddlers who are late talkers. Journal of Child Language, 43(5), 1020-1037.

Mani, N., \& Huettig, F. (2012). Prediction during language processing is a piece of cake-but only for skilled producers. Journal of Experimental Psychology: Human Perception and Performance, 38(4), 843-847.

McGregor, K. K., Friedman, R. M., Reilly, R. M., \& Newman, R. M. (2002). Semantic representation and naming in young children. Journal of Speech, Language, and Hearing Research, 45(2), 332-346.

McMurray, B., \& Aslin, R. N. (2004). Anticipatory eye movements reveal infants' auditory and visual categories. Infancy, 6(2), 203-229.

McMurray, B., Munson, C., \& Tomblin, J. B. (2014). Individual differences in language ability are related to variation in word recognition, not speech perception: evidence from eye movements. Journal of Speech, Language, and Hearing Research, 57(4), 1344-1362.

McMurray, B., Samelson, V. M., Lee, S. H., \& Tomblin, J. B. (2010). Individual differences in online spoken word recognition: implications for SLI. Cognitive Psychology, 60(1), 1-39.
Mishra, J., \& Hillyard, S. A. (2009). Endogenous attention selection during binocular rivalry at early stages of visual processing. Vision Research, 49(10), 1073-1080.

Montero Perez, M., Peters, E., \& Desmet, P. (2015). Enhancing vocabulary learning through captioned video: an eye-tracking study. The Modern Language Journal, 99(2), 308-328.

Montgomery, J. W., Evans, J. L., \& Gillam, R. B. (2009). Relation of auditory attention and complex sentence comprehension in children with specific language impairment: a preliminary study. Applied Psycholinguistics, 30(1), 123-151.

Moon, S. B., \& Byun, C. J. (2003). Korean Kaufman assessment battery for children (K-ABC). Seoul: Hakjisa.

Nation, K., Marshall, C. M., \& Altmann, G. T. (2003). Investigating individual differences in children's real-time sentence comprehension using language-mediated eye movements. Journal of Experimental Child Psychology, 86(4), 314-329.

Noterdaeme, M., Amorosa, H., Mildenberger, K., Sitter, S., \& Minow, F. (2001). Evaluation of attention problems in children with autism and children with a specific language disorder. European Child \& Adolescent Psychiatry, 10(1), 58-66.

Oetting, J. B., Rice, M. L., \& Swank, L. K. (1995). Quick incidental learning (QUIL) of words by school-age children with and without SLI. Journal of Speech, Language, and Hearing Research, 38(2), 434-445.

Pellicer-Sánchez, A. (2016). Incidental L2 vocabulary acquisition from and while reading: an eye-tracking study. Studies in Second Language Acquisition, 38(1), 97-130.

Pivneva, I., Mercier, J., \& Titone, D. (2014). Executive control modulates crosslanguage lexical activation during L2 reading: evidence from eye movements. Journal of Experimental Psychology: Learning, Memory, and Cognition, 40(3), 787.

Pons, F., Andreu, L., Sanz-Torrent, M. Ò. N. I. C. A., Buil-Legaz, L., \& Lewkowicz, D. J. (2013). Perception of audio-visual speech synchrony in Spanishspeaking children with and without specific language impairment. Journal of Child Language, 40(3), 687-700

Poole, A., \& Ball, L. J. (2006). Eye tracking in HCI and usability research. Encyclopedia of Human Computer Interaction, 1, 211-219.

Rayner, K. (1998). Eye movements in reading and information processing: 20 years of research. Psychological Bulletin, 124(3), 372.

Rayner, K. (2009). Eye movements and attention in reading, scene perception, and visual search. The Quarterly Journal of Experimental Psychology, 
$62(8), 1457-1506$

Rayner, K., Chace, K. H., Slattery, T. J., \& Ashby, J. (2006). Eye movements as reflections of comprehension processes in reading. Scientific Studies of Reading, 10(3), 241-255.

Rice, M. L., \& Bode, J. V. (1993). GAPS in the verb lexicons of children with specific language impairment. First Language, 13(37), 113-131.

Rice, M. L., Buhr, J. C., \& Nemeth, M. (1990). Fast mapping word-learning abilities of language-delayed preschoolers. Journal of Speech and Hearing Disorders, 55(1), 33-42.

Rice, M. L., Buhr, J., \& Oetting, J. B. (1992). Specific-language-impaired children's quick incidental learning of words: The effect of a pause. Journal of Speech, Language, and Hearing Research, 35(5), 1040-1048.

Rice, M. L., Oetting, J. B., Marquis, J., Bode, J., \& Pae, S. (1994). Frequency of input effects on word comprehension of children with specific language impairment. Journal of Speech, Language, and Hearing Research, 37(1), 106122.

Rice, M. L., \& Woodsmall, L. (1988). Lessons from television: children’s word learning when viewing. Child Development, 420-429.

Stevens, C., Sanders, L., \& Neville, H. (2006). Neurophysiological evidence for selective auditory attention deficits in children with specific language impairment. Brain Research, 1111(1), 143-152.

Storch, S. A., \& Whitehurst, G. J. (2002). Oral language and code-related precursors to reading: evidence from a longitudinal structural model. Developmental Psychology, 38(6), 934-947.

Tanenhaus, M. K., Spivey-Knowlton, M. J., Eberhard, K. M., \& Sedivy, J. C. (1995). Integration of visual and linguistic information in spoken language comprehension. Science, 268(5217), 1632-1634.

Torppa, M., Lyytinen, P., Erskine, J., Eklund, K., \& Lyytinen, H. (2010). Language development, literacy skills, and predictive connections to reading in Finnish children with and without familial risk for dyslexia. Journal of Learning Disabilities, 43(4), 308-321.

Trueswell, J. C. (2008). Using eye movements as a developmental measure within psycholinguistics. In I. A. Sekerina, E. M. Fernández, \& H. Clahsen (Eds.),
Developmental psycholinguistics: On-line methods in children’s language processing (pp. 73-96). Amsterdam: John Benjamins.

Trueswell, J. C., \& Gleitman, L. R. (2007). Learning to parse and its implications for language acquisition. In G. Gaskell (Ed.), Oxford handbook of psycholinguistics (pp. 635-656). Oxford, England: Oxford University Press.

Williams, R., \& Morris, R. (2004). Eye movements, word familiarity, and vocabulary acquisition. European Journal of Cognitive Psychology, 16(1-2), 312-339.

Wochna, K. L., \& Juhasz, B. J. (2013). Context length and reading novel words: an eye-movement investigation. British Journal of Psychology, 104(3), 347363.

Yang, Y., \& Yim, D. (2018). The role of executive function for vocabulary acquisition and word learning in preschool-age children with and without vocabulary delay. Communication Sciences \& Disorders, 23(1), 43-59.

Yang, Y., Yim, D., \& Bae, K. (2015). Predictors of word learning in children with specific language impairment. Communication Sciences \& Disorders, 20(1), 1-12.

Yang, Y., Yim, D., Kim, S., \& Han, J. (2013). The relationship among receptive vocabulary, non-word repetition, and quick incidental learning in preschoolers with and without delay in vocabulary development. Communication Sciences \& Disorders, 18(4), 379-391.

Yarbus, A. L. (1967). Eye movements during perception of complex objects. In L. Riggs (Ed.), Eye Movements and Vision (pp. 171-211). New York: Plenum Press.

Yim, D., Kim, S., \& Yang, Y. (2015). Factor analysis of working memory tasks based on information processing characteristics: predictive factors of receptive vocabulary and quick incidental learning in children with typically developing and receptive vocabulary delay. Communication Sciences \& Disorders, 20(2), 304-31.

Yu, C., \& Smith, L. B. (2011). What you learn is what you see: using eye movements to study infant cross-situational word learning. Developmental Science, 14(2), 165-180. 
Haeun Chung, et al. • Eye Tracking Study of Incidental Word Learning

Appendix 1. Novel words in quick incidental learning (QUIL) task

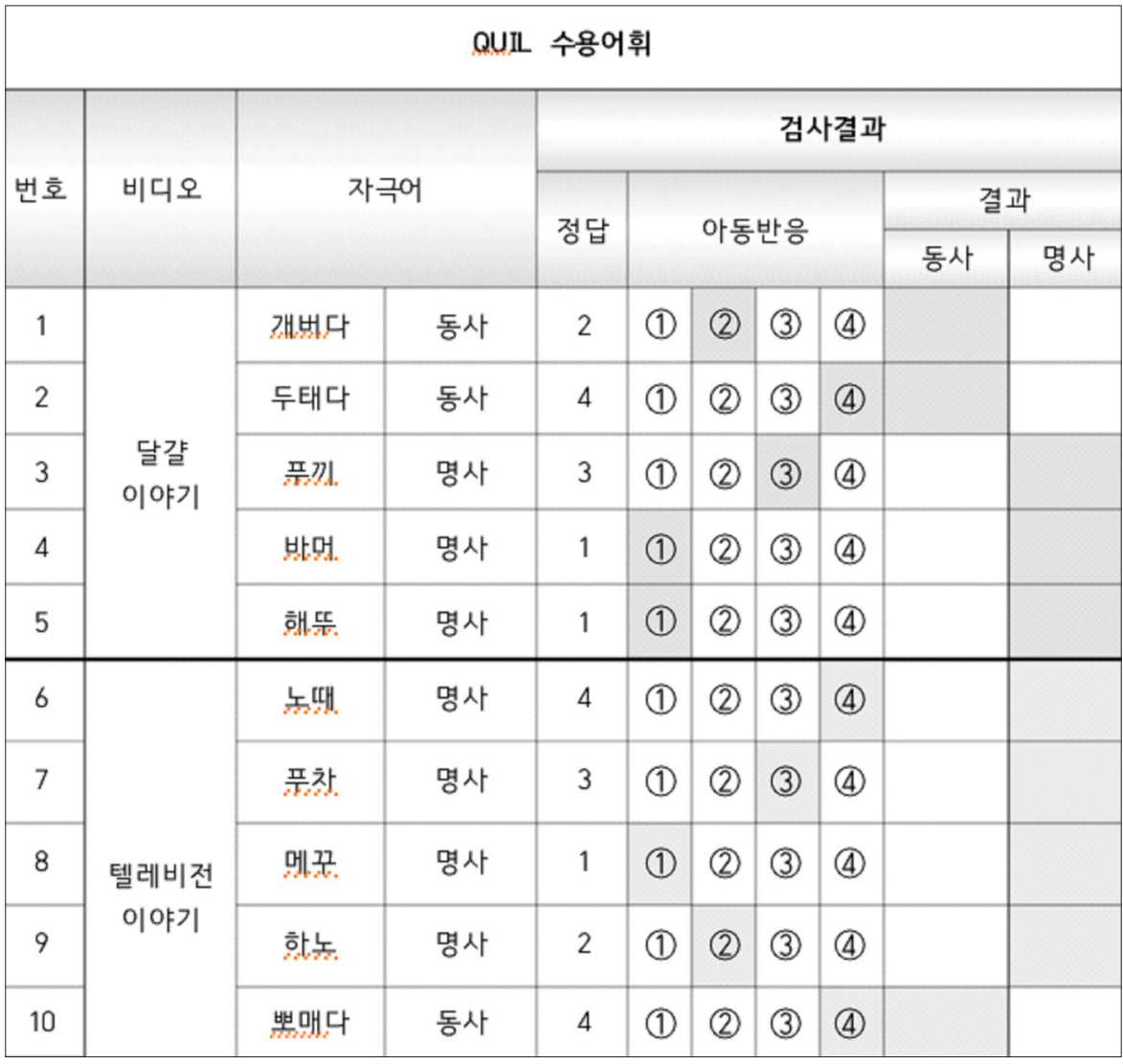


Appendix 2. Quick incidental learning (QUIL) video script

\begin{tabular}{|c|c|}
\hline \multicolumn{2}{|l|}{ 텔레비전 이야기 } \\
\hline 토토에요. & 텔레비전이 이상해요. \\
\hline 예쁜 꽃이 많아요. & 텔레비전이 안 나와요. \\
\hline 토토가 *하노를 불어요. & 아저씨가 텔레비전을 망가뜨려요. \\
\hline 아저씨가 맞았어요. & 아저씨가 놀랬어요. \\
\hline 또 하노를 불어요. & 아저씨가 화가 났어요. \\
\hline 아저씨가 맞았어요. & 아저씨가 토토집을 망가뜨려요. \\
\hline 토토가 하노를 주워요. & 토토가 아저씨를 * 뽀매요. \\
\hline 아저씨는 화가 났어요. & 토토가 아저씨를 뽀매요. \\
\hline 아저씨가 물을 줘요. & 토토가 계속 뽀매요. \\
\hline 아저씨가 집에 들어가요. & 아저씨가 화났어요. \\
\hline 아저씨가 텔레비전을 봐요. & 화가 많이 났어요. \\
\hline 쥐에요. & 토토가 쥐를 불러요. \\
\hline 텔레비전에 토토가 나왔어요. & 같이 꽃을 심어요. \\
\hline 쥐가 달려가요. & 아저씨가 푸차를 가져와요. \\
\hline 쥐가 토토를 불러요. & 도망가요! \\
\hline 쥐랑 토토랑 달려가요. & 어! *메꾸를 떨어뜨렸어요. \\
\hline *푸차에요! & 아저씨가 메꾸를 들어요. \\
\hline 집에 뿌려요. & 메꾸를 집에 꽃아요. \\
\hline 집이 비너요. & 아저씨는 푸차를 버려요. \\
\hline 와! 무서워요. & 다 비너요. \\
\hline 토토가 깜짝 놀랐어요. & 비너서 없어졌어요. \\
\hline 토토가 *노때를 흔들어요. & 아저씨는 토토를 불러요. \\
\hline 토토가 노때에 매달려요. & 토토가 나왔어요. \\
\hline \multicolumn{2}{|l|}{ 노때가 부러졌어요. } \\
\hline \multicolumn{2}{|l|}{ 달걀 이야기 } \\
\hline 꼬꼬댁 꼬꼬에요. & 틀에 빠졌어요. \\
\hline 꼬꼬가 놀랐어요. & 어디로 가는거지 \\
\hline 토토에요. & 뜨거워요. \\
\hline 어? 달걀이에요. & 어디가니 \\
\hline 토토가 *개버요. & 삐약삐약 삐약이가 뛰어다녀요. \\
\hline 토토가 개버요. & 바머가 과자가 됐어요. \\
\hline 토토가 또 개버요. & 삐약이가 과자를 먹어요. \\
\hline 우와 달걀이 많아요. & 토토가 삐약이를 쫓아가요. \\
\hline 달걀이 트럭에서 *두태요. & 위험해 \\
\hline 달걀이 하나씩 두태요. & 삐약이가 *해뚜에 빠졌어요. \\
\hline 토토에요. & 해뚜가 많아요. \\
\hline 토토도 두태요. & 토토랑 삐약이가 해뚜에서 나왔어요. \\
\hline 달걀이 삐약삐약 & 토토가 삐약이랑 뛰어가요. \\
\hline 삐약이가 됐어요. & 강아지가 토토한테 알려줘요. \\
\hline 조심해. & 토끼가 토토한테 알려줘요. \\
\hline 달걀이 떨어져요. & 꼬꼬댁 꼬꼬가 울고 있어요. \\
\hline 떨어져요. & 여기 삐약이야 \\
\hline 밀가루를 뿌렸어요. & 꼬꼬랑 삐약이가 만났어요. \\
\hline 커다란 *푸끼에요. & 꼬꼬랑 삐약이가 행복해 보여요. \\
\hline 푸끼가 돌아가요. & 토토가 과자를 줘요. \\
\hline 푸끼가 *바머를 만들어요. & 안녕 \\
\hline 바머를 틀에 짜요. & \\
\hline
\end{tabular}




\section{국문초록}

\section{단순언어장애 아동과 정상 발달 아동의 빠른 우연 학습 능력: 시선 추적 연구 \\ 정하은 · 임동선 \\ 이화여자대학교 언어병리학과}

배경 및 목적: 본 연구의 목적은 시선추적기를 활용해 단순언어장애 아동과 정상 발달 아동이 새로운 어휘 학습 시에 보이는 실시간 처 리 어려움을 살펴보고, 빠른 우연 학습 수행에 영향을 미치는 요인을 밝히고자 하였다. 방법: 만 4-6세의 단순언어장애 아동 10 명과 일 반아동 20 명이 참여했으며, 이들을 대상으로 빠른우연학습 과제를 실시하였다. 결과: 정상 발달 아동이 단순언어장애 아동에 비해 빠 른우연학습 과제의 어휘학습 평가에서 유의하게 높은 점수를 획득하였다. 두 집단 간에 시선 고정 횟수에서는 유의한 차이가 없었으나, 평균 고정 시간은 그룹 간 유의한 차이가 나타났다. 또한, 여러 번의 노출에 따른 평균 고정 시간을 살펴본 결과, 정상 발달 아동의 고정 시간은 첫 번째 노출에서 마지막 노출까지 점진적으로 증가한 반면, 단순언어장애 아동은 고정 시간이 감소하는 패턴이 나타났다. 논의 및 결론: 빠른 우연 학습 과제에서 단순 언어 장애 아동은 어휘와 해당 어휘가 지칭하는 물체를 성공적으로 연결 시키는 데 어려움을 보 였으며, 또한 과제 후반부까지 지속적으로 주의 집중을 유지하는 데에 어려움을 보였다. 본 연구를 통해 단순언어장애 아동의 빠른 우 연 학습 과제에서 보이는 저조한 수행은 새로운 어휘를 탐지하여 처리하는 데에 관여하는 주의 기능의 결함에 기인한 것으로 추측된다.

핵심어: 빠른우연학습, 시선추적기, 단순언어장애

본 연구는 2020년 대한민국 과학기술정보통신부와 한국연구재단의 지원을 받아 수행된 연구임(NRF-2019R1A2C1007488).

\section{참고문헌}

강시내, 임동선(2018). 시선 추적기를 활용한 학령기 단순언어장애 아동의 이야기 읽기 이해력과 읽기 처리과정 연구. Communication Sciences and Disorders, 23(4), 914-928.

김영태, 성태제, 이윤경(2003). 취학전 아동의 수용언어 및 표현언어척도(PRES). 서울: 서울장애인종합복지관.

문수백, 변창진(2003). K-ABC 교육. 심리 측정도구(Korean-Kaufman assessment battery for children: K-ABC). 서울: 학지사.

양윤희, 임동선(2018). 학령전기 어휘발달지연 및 또래 아동의 어휘습득을 위한 집행기능의 역할. Communication Sciences \& Disorders, 23(1), 43-59. 양윤희, 임동선, 김신영, 한지윤(2013). 학령 전 어휘발달지체 및 일반 아동의 비단어 따라 말하기, 빠른 우연학습과 수용어휘와의 관계. Communication Sciences and Disorders, 18(4), 379-391.

양윤희, 임동선, 배경란(2015). 학령기 단순언어장애 아동의 어휘학습 예측요인: 의미점화 및 간섭 효과. Communication Sciences \& Disorders, 20(1), 1-12.

임동선, 김신영, 양윤희(2015). 정보처리 특성에 따른 작업기억 과제의 탐색적 요인분석: 일반아동 및 수용어휘지체 아동의 수용어휘력 및 빠른우연

학습 예측요인. Communication Sciences \& Disorders, 20(2), 304-318.

\section{ORCID}

정하은(제1저자, 대학원생 https://orcid.org/0000-0001-5113-1754); 임동선(교신저자, 교수 https://orcid.org/0000-0001-8254-9504) 